\title{
SAUDAÇÃO PROFERIDA PELO PROFESSOR EROS ROBERTO GRAU À NOVA TITULAR, PROFESSORA MARIA SYLVIA ZANELLA DI PIETRO
}

Exmo. Professor Antonio Junqueira de Azevedo, Diretor da Faculdade de Direito Douta Congregação

Minhas Senhoras, meus Senhores

Eminente Professora Maria Sylvia Zanella Di Pietro

Fui incumbido ... e isso muito me honra e desvanece ... de saudar a Professora Doutora Maria Sylvia Zanella Di Pietro, em nome da Congregação, nesta cerimônia de sua recepção como Professora Titular da Faculdade de Direito do Largo de São Francisco.

Esta é uma cerimônia de celebração. Celebramos, como recomenda a nossa tradição, a nomeação da nova Professora Titular. E, ao mesmo tempo, celebramos as nossas tradições.

A tradição recomenda àquele que pronuncia o discurso de saudação ao novo Professor, desenvolva exposição a respeito do seu memorial, porque aí se pode encontrar as datas, eventos e obras que marcam seu perfil intelectual. Tudo isso, contudo, pode ser sinteticamente enunciado em uma só alusão, alusão ao fato de que estou a saudar Professora Titular do Largo de São Francisco.

Ser Professor do Largo de São Francisco, fruir a sensação de sê-lo. Sentir, sem nenhuma arrogância, despretensiosamente, a sensação que nos toma a espinha, penetrando o coração, quando cruzamos as Arcadas. Pertencer à Academia. Pertencer a ela por direito conquistado através de concursos, que dela faz, inteira e completamente única, a Academia de Direito do Largo de São Francisco.

Isso diz tudo, Professora.

Aqui estamos, vencidas as etapas de tantos concursos ... o mestrado, o doutorado, a livre-docência, o concurso para Titular.

Aqui está a Professora Doutora Maria Sylvia Zanella Di Pietro, aluna do Largo de São Francisco, da turma de 1966, portando a dissertação de mestrado (Servidões Administrativas), a tese de doutorado (Uso Privativo de Bem Público 
por Particular), a tese de livre-docência (Do Direito Privado na Administração Pública), a tese para concurso de titular (Discricionariedade Administrativa na Constituição de 1988).

Aqui a Professora Doutora Maria Sylvia Zanella Di Pietro, cuja produção científica não se esgota nesses livros, cuja atividade didática a fazem respeitada pelos alunos do curso de graduação e do curso de pós-graduação; a Professora Doutora Maria Sylvia Zanella Di Pietro, cujo compêndio Direito Administrativo é adotado como texto de ensino em inúmeros cursos de Direito, em todo o Brasil.

Desejo, porém, exceder a exposição a respeito das datas, eventos e obras que marcam o perfil intelectual da nova Professora Titular, para referir a figura que desperta admiração pelo tanto de prudência que cultiva.

Refiro-me, neste passo, à prudência (phrónesis) que o Direito é e que reclama, para que possa ser atingida, a prática do hábito, tão negligenciado, da reflexão.

Refiro-me à phrónesis, tal como dela cogita Aristóteles, na Ética a Nicomano, que não é ciência nem arte: é uma virtude (VI, 51.140 b.20). A prudência é uma disposição (capacidade), acompanhada de razão, capaz de agir na esfera do que é bom ou mau para um ser humano (VI, 51.140 b,5); ou, dizendo-o de outro modo, capaz de agir na esfera dos bens humanos (VI, 51.140 b.20). A prudência é, pois, razão intuitiva, que não discerne o exato, porém o correto ... não é saber puro, separado do ser. Isso, uma phrónesis, é interpretar/aplicar o Direito.

Posso, mercê da convivência com a Professora, na Comissão de PósGraduação de nossa Faculdade, nela discernir a autêntica juris prudente, que todos almejamos ser ... ou deveríamos almejar ser.

Importa deixarmos bem-vincado, contudo, neste momento em que celebramos a nomeação da nova Professora Titular e as nossas tradições, que aqui, no cotidiano, incumbe-nos celebrar o Direito. Essa a nossa missão; essa a nossa vocação.

Meus olhos visualizam o presente e sou tomado de temor diante da gravidade do presente, a convocar a Professora Titular do Departamento de Direito do Estado, à celebração do Direito, tão necessária no momento presente.

Vivemos um momento cinzento, de abandono da reflexão e da prudência. A violência da sociedade brasileira nega a tese do homem cordial que 
habitaria a individualidade dos brasileiros. Aqui os linchamentos fazem parte do cotidiano. Vivemos sob um Estado que não é capaz de exercer com proficiência o monopólio da força, nos quadrantes da legalidade e do procedimento legal. E isso importa em que a força seja detida por quem desconhece a legalidade e o procedimento legal. Lincha o povo, quando a polícia não chega a tempo de proteger o assaltante contra a sua fúria, assim como lincha a imprensa, no tribunal de exceção erigido sobre a premissa de que todos são culpados até prova em contrário.

O homem cordial de Sérgio Buarque de Holanda já não senta à nossa mesa. E a consciência jurídica nacional, nesse clima, sucumbe ao desvario da ordália.

É largo e profundo o descaminho que a maioria toma. E tanto, tanto, que a convocação à celebração do Direito exige coragem. Porque a celebração do Direito, Professora ... e Vossa Excelência sabe disso ... impõe a irrestrita, completa, absoluta afirmação do direito de defesa dos acusados. Espanto-me, causa-me verdadeiro estupor ouvir o silêncio daqueles que se calam diante da substituição dos parâmetros da lei pela verdade da mídia.

Espanta-me, também, Professora, causa-me verdadeiro estupor observar que a sociedade corre o risco de ser embalada pela tese da Assembléia Revisora Exclusiva, integrada por homens bons, vedando-se a participação nela de políticos ... pois é isso o que se pretende, ainda que não se o diga às claras.

Diante desse retorno ao pensamento conservador dos séculos XVIII e XIX, diante dessa disfarçada agressão à representatividade e ao sufrágio universal ... porque é a proposta de uma democracia censitária que se oculta sob essa tese (mais adiante os seus mentores assumirão que os pardos, os mamelucos e os cafusos não poderão votar, além de não poderem ser eleitos) ... diante dessa disfarçada agressão à representatividade e ao sufrágio universal, eu dizia, a celebração do Direito se impõe.

Para nós, que repudiamos as oligarquias e os golpes contra a ordem constitucional, o sacrificio dos partidos políticos e do exercício da política é inadmissivel.

Por isso, Professora, a cerimônia de que ora participo, de celebração de vossa nomeação, no que celebramos o Direito, com o vigor de vossa prudência 
jurídica, me enche de esperança. Esperança de não ser compelido a repetir, um dia, um trecho de poema de Vinícius de Moraes: "Pátria minha, tão pobrinha!".

Eu vos saúdo, Professora, em nome da Congregação e em meu nome também. 